\title{
Penggunaan Metode Ward dalam Pengelompokan Kabupaten/Kota di Provinsi Aceh Berdasarkan Indikator Tanaman Pangan dan Perkebunan
}

\author{
NaNy SAlwa, NuRHasanaH, Salmiati \\ Jurusan Matematika FMIPA UNSYIAH \\ Jl. Syech Abdul Rauf No.3 Darussalam, Banda Aceh \\ Email: nanysalwa@gmail.com,nurhasanah.math@gmail.com
}

\begin{abstract}
ABSTRAK
Penelitian ini dilakukan untuk mengidentifikasi kelompok kabupaten/kota di Provinsi Aceh berdasarkan luas tanam komoditas subsektor tanaman pangan dan perkebunan. Luas tanam kedua subsektor pangan dan perkebunan tersebut meliputi luas tanam tanaman padi, jagung, kedelai, kacang tanah, ubi jalar, ubi kayu, kelapa sawit, karet, kakao, kelapa, pinang, dan kopi. Metode pengelompokan yang digunakan adalah metode Ward dengan menerapkan 2 konsep jarak, yaitu jarak korelasi Pearson dan jarak Euclidean. Konsep jarak korelasi Pearson digunakan pada data dengan kasus multikolinieritas, sedangkan konsep jarak Euclidean digunakan pada data tanpa multikolinearitas. Pengelompokan dengan konsep jarak Euclidean dilakukan dengan meniadakan masalah multikolinieritas terlebih dahulu, yaitu dengan menggunakan analisis komponen utama. Hasil penelitian menunjukan bahwa pengelompokan dengan konsep jarak Euclidean lebih baik dibandingkan pengelompokan dengan jarak korelasi Pearson. Hal ini diketahui dari nilai rasio antara ragam dalam cluster dan ragam antar cluster, jika rasionya semakin kecil maka semakin baik pengelompokannnya. Hasil pengelompokan 6 Cluster dengan metode jarak Euclidean menunjukan bahwa cluster 2 dominan pada komoditas tanaman padi, ubi kayu, pinang dan kelapa. Cluster 3 didominasi oleh komoditas tanaman kacang tanah, kelapa sawit dan karet. Cluster 4 didominasi komoditas tanaman jagung dan kakao. Komoditas yang dominan pada Cluster 6 berupa komoditas ubi jalar dan kopi. Sementara cluster 1 dan cluster 3 merupakan dua kelompok kabupaten yang tidak memiliki komoditas tanaman pangan dan perkebunan yang dominan.
\end{abstract}

Kata Kunci: Pengelompokan, luas tanam, metode Ward, korelasi Pearson, Euclidean, analisis komponen utama

\section{PENDAHULUAN}

Analisis cluster merupakan teknik multivariat yang mempunyai tujuan untuk mengelompokkan objek berdasarkan karakteristik yang dimiliki. Salah satu metode pengelompokan data dalam analisis cluster yaitu metode pengelompokan hirarki. Terdapat beberapa metode pengelompokan analisis cluster hirarki antara lain metode pautan tunggal (single linkage), pautan lengkap (complete linkage), pautan rata-rata (average linkage), metode centroid dan metode Ward. Masing-masing metode ini memiliki perbedaan cara pengelompokan. Menurut Field (2000), metode Ward merupakan metode yang berbeda dari metode pautan lainnya, metode ini jauh lebih kompleks dari metode pautan sederhana. Menurut Cornish (2007), metode Ward merupakan salah satu metode yang paling popular digunakan selain metode pautan rata-rata.

Analisis cluster telah diterapkan dalam berbagai sektor, antara lain dalam sektor ekonomi, sektor kesehatan, sektor pendidikan dan sektor pertanian. Salah satu langkah yang dapat dilakukan untuk meningkatkan pertumbuhan sektor pertanian di Provinsi Aceh adalah melakukan identifikasi daerah yang memiliki kemiripan komoditas dominan di setiap kabupaten/kota. Hal ini akan lebih mudah dilakukan jika kabupaten/kota dikelompokkan berdasarkan kemiripan potensi sektor pertanian. Salah satu indikator komoditas unggul di suatu kabupaten/kota dapat ditinjau dari luas tanamnya. Oleh karena itu identifikasi 
komoditas dominan di Provinsi Aceh dapat dilakukan berdasarkan luas tanam setiap komoditas.

\section{TINJAUAN PUSTAKA}

\section{Analisis Komponen Utama}

Analisis komponen utama adalah suatu teknik analisis multivariat untuk mengubah data asli yang saling berhubungan (saling berkorelasi) satu dengan yang lain menjadi data baru yang lebih sederhana dan tidak berkorelasi lagi Menurut Mattjik dan Sumertajaya (2011), komponen utama merupakan kombinasi linear dari peubah yang diamati, informasi yang terkandung pada komponen utama merupakan gabungan dari semua peubah dengan bobot tertentu atau dapat ditulis :

$\mathrm{Y}=\mathrm{A} \mathrm{X}$

dimana

$$
Y=\left[\begin{array}{c}
\mathrm{Y}_{1} \\
\vdots \\
\mathrm{Y}_{\mathrm{p}}
\end{array}\right] \quad A=\left[\begin{array}{ccc}
a_{11} & \cdots & a_{1 p} \\
\cdots & \ddots & \cdots \\
a_{p 1} & \cdots & a_{p p}
\end{array}\right] \quad X=\left[\begin{array}{c}
\mathrm{X}_{1} \\
\vdots \\
\mathrm{X}_{\mathrm{p}}
\end{array}\right]
$$

Menurut Mattjik dan Sumertajaya (2011), terdapat tiga metode yang umum digunakan dalam menentukan jumlah komponen utama yaitu :

1) Apabila banyaknya komponen utama yang dihasilkan adalah $q$ dimana $q \leq p$, maka yang telah ditranformasi (data skor komponen utama mempunyai peubah sebanyak $p$. Misalkan proporsi untuk akar ciri ke-j adalah:

$$
\frac{\lambda_{\mathrm{j}}}{\sum_{j=1}^{p} \lambda_{\mathrm{j}}}
$$

Maka penentuan banyaknya komponen utama $(q)$ didasarkan proporsi kumulatif dari akar-akar cirinya.

2) Bedasarkan pada ragam komponen utama, yang tidak lain adalah akar ciri yaitu 0.7. Metode ini hanya bisa diterapkan pada penggunaan matriks korelasi. Ketika menggunakan matriksini, peubah asal ditransformasikan menjadi peubah yang memiliki ragam sama yaitu satu.

3) Penggunaan grafik plot scree. Plot scree merupakan plot antara akar ciri $\lambda_{k}$ dengan $k$. Dengan menggunakan plot ini, banyaknya komponen utama yang terpilih adalah $k$, jika pada titik $k$ tersebut plotnya curam ke kiri tapi tidak curam ke kanan.

\section{Analisis Cluster}

Analisis cluster merupakan teknik peubah ganda yang mempunyai tujuan utama untuk mengelompokkan objek-objek berdasarkan kemiripan karakteristik yang dimiliknya. Karakteristik objek-objek dalam suatu cluster memiliki tingkat kemiripan yang tinggi, sedangkan karakteristik antar objek pada suatu cluster lain memiliki tingkat kemiripan yang rendah (Mattjik dan Sumertajaya, 2011).

Kemiripan antar objek dapat diukur dengan menggunakan ukuran jarak. Terdapat beberapa jenis jarak kedekatan yang sering digunakan dalam analisis cluster, antara lain jarak Euclidean, jarak Mahalanobis, jarak City-block (Manhattan), dan lain-lain (Mattjik dan Sumertajaya, 2011).

1) Jarak Euclidean

Menurut Rencher (2002), ukuran jarak yang sering digunakan dalam analisis cluster adalah jarak Euclidean. Jarak ini digunakan jika peubah-peubah yang diamati tidak berkorelasi. 
fungsi jarak antara dua buah vektor $\mathbf{x}=\left(x_{1}, x_{2}, \cdots, x_{p}\right)^{\prime}$ dan $\mathbf{y}=\left(y_{1}, y_{2}, \cdots, y_{p}\right)^{\prime}$, didefinisikan:

$$
\begin{aligned}
\mathrm{d}(\mathrm{x}, \mathrm{y}) & =\sqrt{(\mathrm{x}-\mathrm{y})^{\prime}(\mathrm{x}-\mathrm{y})} \\
& =\left(\sqrt{\sum_{\mathrm{j}=\mathrm{i}}^{\mathrm{p}}\left(\mathrm{x}_{\mathrm{j}}-\mathrm{y}_{\mathrm{j}}\right)^{2}}\right.
\end{aligned}
$$

2) Jarak korelasi pearson

Jarak korelasi pearson merupakan jarak yang mengevaluasi sejauh mana suatu objek memiliki hubungan satu sama lain (Vijverbeg, 2007). Jarak ini digunakan apabila terdapat multikolinearitas pada peubah. Rumus fungsi jarak korelasi pearson adalah sebagai berikut:

$d(i, j)=1-r_{i j}$

dengan $d(i, j)=$ jarak korelasi pearson

$$
r_{i j} \quad=\text { koefisien korelasi }
$$

Koefisien korelasi dapat dihitung dengan rumus:

$r_{i j}=\frac{\operatorname{cov}\left(X_{i}, X_{j}\right)}{\sqrt{\operatorname{var}\left(X_{i}\right) \operatorname{var}\left(X_{j}\right)}}$

dengan

$$
\begin{array}{ll}
\operatorname{cov}\left(X_{i}, X_{j}\right) & =\text { peragam variable } X i \text { dan } X j \quad \operatorname{var}\left(X_{i}\right)=\text { ragam variabel ke-i } \\
\operatorname{var}\left(X_{j}\right) & =\text { ragam variabel ke-j. }
\end{array}
$$

Salah satu metode pengelompokan data dalam analisis cluster yaitu metode clustering hirarki. Metode clustering hirarki adalah metode pengelompokan data yang mengelompokan sejumlah data ke dalam beberapa cluster tanpa ditentukan jumlah cluster sebelumnya.

Ada lima metode clustering hirarki aglomeratif dalam pembentukan cluster yaitu pautan tunggal (single linkage), pautan lengkap (complete linkage), pautan rata-rata (average linkage), metode Ward (Ward's method) dan metode centroid (Rencher, 2002).

Menurut Field (2000), metode Ward merupakan metode yang berbeda dari metode linkage lainnya, metode ini jauh lebih kompleks dari metode linkage sederhana. Metode Ward juga disebut dengan metode jumlahan kuadrat karena jarak antar dua cluster pada metode ini adalah total jumlah kuadrat dua cluster pada masing-masing peubah (Rencher, 2002). Metode ini menggunakan pendekatan analisis varians untuk menghitung jarak antar cluster.

Metode Ward didasarkan pada kriteria sum square error (SSE) dengan ukuran kehomogenan antara dua objek berdasarkan jumlah kuadrat kesalahan yang paling minimal. SSE hanya dapat dihitung jika cluster memiliki elemen lebih dari satu objek. Secara umum, formula SEE (Johnson dan Wichern, 2002) adalah sebagai berikut:

$$
(S S E)=\sum_{I=1}^{n}\left(x_{i}-\bar{x}\right)^{\prime}\left(x_{i}-\bar{x}\right)
$$

dimana $x_{i}$ adalah vektor kolom yang berisikan rata-rata nilai objek $i$ dengan $i=1,2, \ldots, n$. $\bar{x}$ adalah vektor kolom yang $x$ rata-rata nilai objek dalam cluster, n adalah banyaknya objek.

Jika AB adalah cluster yang diperoleh dengan menggabungkan cluster A dan B, maka jumlah kuadrat di dalam cluster adalah

$$
\begin{aligned}
& \left(S S E_{A}\right)=\sum_{I=1}^{n_{A}}\left(x_{i}-\bar{x}_{A}\right)^{\prime}\left(x_{i}-\bar{x}_{A}\right) \\
& \left(S S E_{B}\right)=\sum_{I=1}^{n_{B}}\left(x_{i}-\bar{x}_{B}\right)^{\prime}\left(x_{i}-\bar{x}_{B}\right) \\
& \left(S S E_{A B}\right)=\sum_{I=1}^{n_{A B}}\left(x_{i}-\bar{x}_{A B}\right)^{\prime}\left(x_{i}-\bar{x}_{A B}\right)
\end{aligned}
$$

dengan $S S E_{A}, S S E_{B}, S S E_{A B}$ adalah jumlah kuadrat kesalahan cluster A, B dan AB. $\bar{x}_{A}, \bar{x}_{B}$ dan $\bar{x}_{A B}$ adalah vektor kolom yang berisikan rata-rata nilai objek dari cluster A, B dan AB. 
74 Nani Salwa, dkk.

$$
\bar{x}_{A B}=\frac{\left(n_{A} \bar{x}_{A}+n_{B} \bar{x}_{B}\right)}{n_{A} n_{B}}, \quad \bar{x}_{A}=\sum_{i=!}^{n_{A}} \frac{x_{i}}{n_{A}}, \bar{x}_{B}=\sum_{i=!}^{n_{B}} \frac{x_{i}}{n_{B}}
$$

Metode Ward menggabungkan dua cluster A dan B dengan meminimalkan peningkatan SSE didefinisikan sebagai jarak antara cluster A dan cluster B yaitu sebagai berikut:

$I_{A B}=S S E_{A B}-\left(S S E_{A}+S S E_{B}\right)$

dengan $I_{A B}$ adalah jarak antara cluster A dan cluster B.

\section{Simpangan Baku}

Sebuah metode pengelompokan yang baik jika mempunyai nilai simpangan baku dalam cluster $\left(V_{w}\right)$ yang minimum dan nilai simpangan baku antar cluster $\left(V_{b}\right)$ yang maksimum (Barakbah dan Arai, 2004).

Menurut Barakbah dan Arai (2004), nilai $V_{w}$ dapat dirumuskan sebagai berikut:

$$
V_{w}=\frac{1}{K} \sum_{k=1}^{K} V_{k}
$$

dengan

$\mathrm{K}$ = Banyaknya cluster yang terbentuk

$V_{k}=$ Simpangan baku cluster ke-k

Simpangan baku cluster didefinisikan:

$V_{k}=\sqrt{\frac{1}{n-1} \sum_{k=1}^{n}\left(x_{i}-\bar{x}_{k}\right)^{2}}$

Simpangan baku antar cluster $\left(V_{b}\right)$ dapat dirumuskan sebagai berikut:

$V_{b}=\left[\frac{1}{(K-1)} \sum_{k=1}^{K}\left(\bar{X}_{k}-\bar{X}\right)^{2}\right]^{1 / 2}$

dengan

$k$ = Banyaknya cluster

$\bar{X}_{k}=$ rataan cluster $\mathrm{ke}-\mathrm{k}$

$\bar{X}_{k}=$ Rataan seluruh cluster

Pengelompokan yang baik akan memiliki nilai $V_{w}$ minimum dan $V_{b}$ maksimum atau dalam hal ini metode terbaik menghasilkan nilai simpangan rasio simpangan baku minimum $V_{w}$ terhadap $V_{b}$ dengan rumus sebagai berikut:

$V=\frac{V_{w}}{V_{b}} \times 100$

dengan

$V_{w}=$ simpangan baku dalam cluster

$V_{b}=$ simpangan baku antar cluster

\section{HASIL DAN PEMBAHASAN}

\section{Pengelompokan Dengan Jarak Korelasi Pearson}

Pengelompokan dengan jarak korelasi Pearson dilakukan pada data luas tanam komoditas masing-masing kabupaten/kota yang mengandung multikolinearitas. Kabupaten/kota dikelompokan menjadi tiga cluster, empat cluster, lima cluster dan enam cluster. 
Hasil pengelompokan kabupaten/kota berdasarkan indikator tanaman pangan dan perkebunan dengan jarak korelasi Pearson untuk tiga cluster pada Gambar 3.1. Berdasarkan Gambar 3.1 diperoleh anggota-anggota cluster hasil pengelompokan yaitu:

1) Cluster I : Kabupaten Simeulu, Aceh Barat Daya, Aceh Jaya, Aceh Singkil, Lhokseumawe, Subussalam, Gayo Lues, Banda Aceh, Langsa dan Sabang.

2) Cluster II : Kabupaten Aceh Tengah dan Bener Meriah.

3) Cluster III : Kabupaten Aceh Selatan, Aceh Besar, Pidie, Pidie Jaya, Bireuen, Aceh Utara, Aceh Tenggara, Aceh Timur, Aceh Tamiang, Nagan Raya dan Aceh Barat.

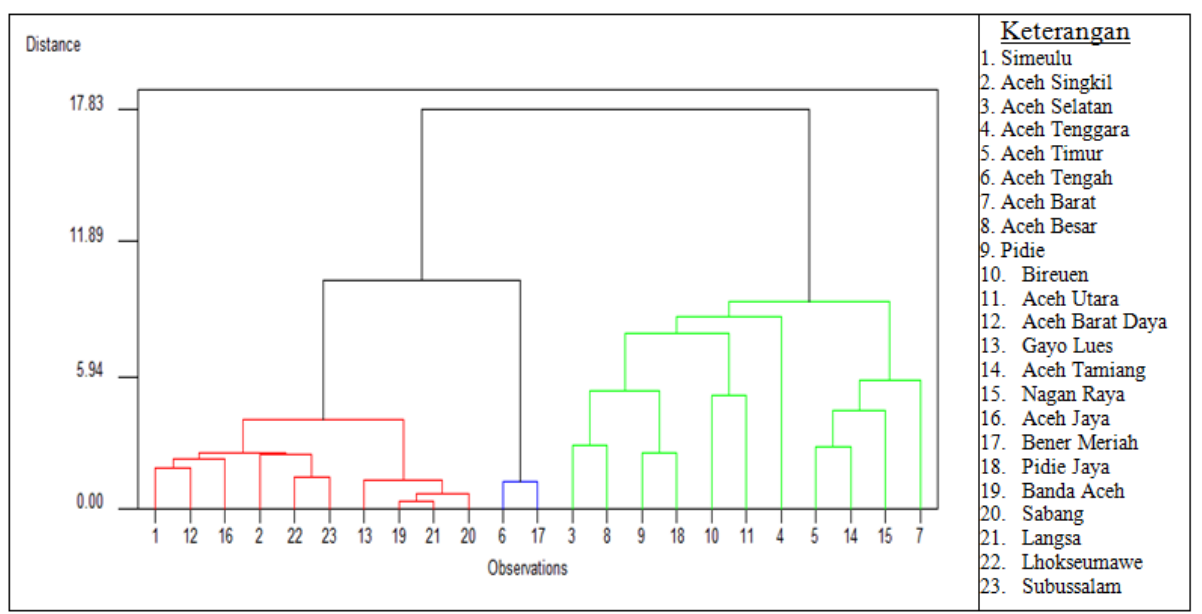

Gambar 3.1. Hasil pengelompokan tiga cluster dengan jarak korelasi Pearson

Hasil pengelompokan kabupaten/kota dengan empat cluster dapat dilihat pada Gambar 3.2. Dari gambar tersebut diperoleh hasil pengelompokan sebagai berikut:

1) Cluster I : Kabupaten Simeulu, Aceh Barat Daya, Aceh Jaya, Aceh Singkil, Lhokseumawe, Subussalam, Gayo Lues, Banda Aceh, Langsa dan Sabang.

2) Cluster II : Kabupaten Aceh Tengah dan Bener Meriah.

3) Cluster III : Kabupaten Aceh Selatan, Aceh Besar, Pidie, Pidie Jaya, Bireuen, Aceh Utara dan Aceh Tenggara.

4) Cluster IV : Kabupaten Aceh Timur, Aceh Tamiang, Nagan Raya dan Aceh Barat.

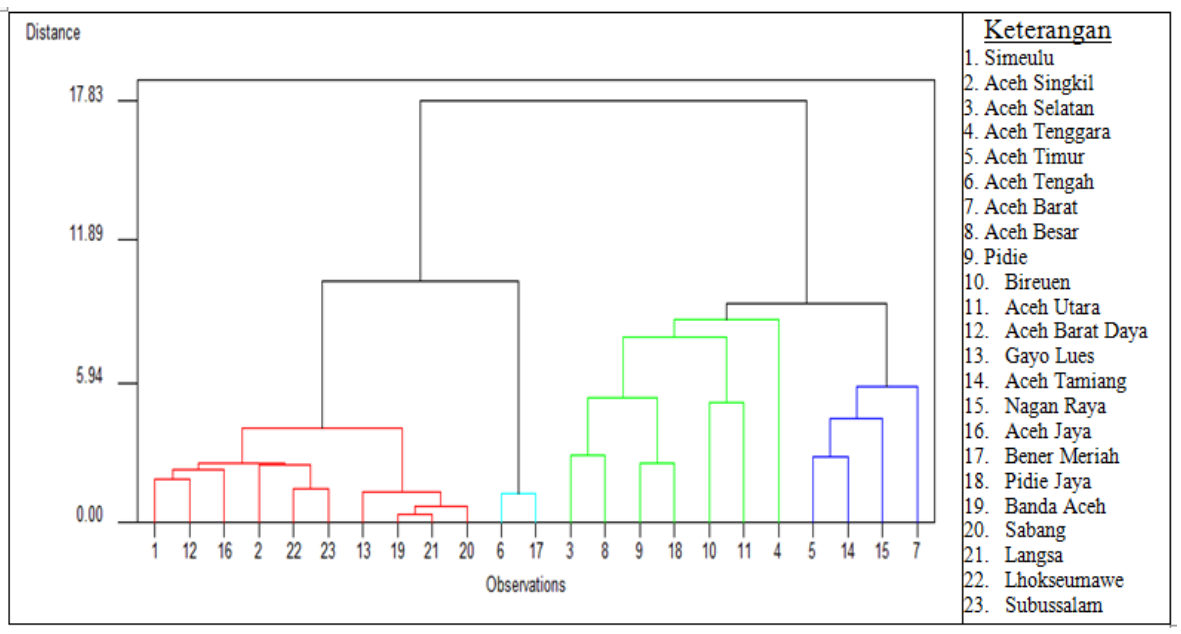

Gambar 3.2. Hasil pengelompokan empat cluster dengan jarak korelasi Pearson 
Berdasarkan nilai rata-rata luas tanam pada masing-masing cluster), maka hasil pengelompokan di atas memiliki nilai simpangan baku dalam cluster sebesar 2.125,83 dan nilai simpangan baku antar cluster sebesar 3.308.

Hasil pengelompokan kabupaten/kota dengan lima cluster dapat dilihat pada Gambar 3.3. Berdasarkan Gambar 3.3 diperoleh anggota-anggota cluster hasil pengelompokan kabupaten/kota dengan jarak korelasi Pearson untuk lima cluster yaitu:

1) Cluster I : Kabupaten Simeulu, Aceh Barat Daya, Aceh Jaya, Aceh Singkil, Lhokseumawe, Subussalam, Gayo Lues, Banda Aceh, Langsa dan Sabang.

2) Cluster II : Kabupaten Aceh Tengah dan Bener Meriah.

3) Cluster III : Kabupaten Aceh Selatan, Aceh Besar, Pidie, Pidie Jaya, Bireuen dan Aceh Utara.

4) Cluster IV : Kabupaten Aceh Timur, Aceh Tamiang, Nagan Raya dan Aceh Barat.

5) Cluster V : Kabupaten Aceh Tenggara.

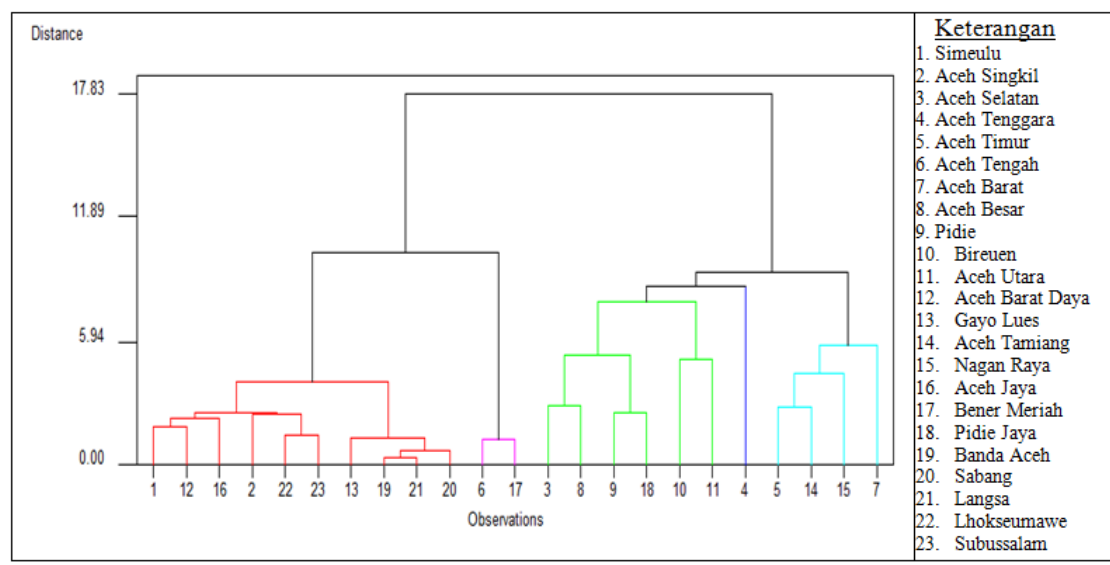

Gambar 3.4. Hasil pengelompokan lima cluster dengan jarak korelasi Pearson

Berdasarkan nilai rata-rata luas tanam pada masing-masing cluster, maka hasil pengelompokan di atas memiliki nilai simpangan baku dalam cluster sebesar 1.755,01 dan nilai simpangan baku antar cluster sebesar 2.983,63.

Hasil pengelompokan kabupaten/kota dengan enam cluster dapat dilihat pada Gambar 3.5. Dari Gambar 3.5 diperoleh hasil pengelompokan sebagai berikut:

1) Cluster I : Kabupaten Simeulu, Aceh Barat Daya, Aceh Jaya, Aceh Singkil, Lhokseumawe, Subussalam, Gayo Lues, Banda Aceh, Langsa dan Sabang.

2) Cluster II : Kabupaten Aceh Tengah dan Bener Meriah.

3) Cluster III : Kabupaten Aceh Selatan, Aceh Besar, Pidie dan Pidie Jaya.

4) Cluster IV : Kabupaten Aceh Timur, Aceh Tamiang, Nagan Raya dan Aceh Barat.

5) Cluster V : Kabupaten Aceh Tenggara.

6) Cluster VI : Kabupaten Bireuen dan Aceh Utara.

Berdasarkan nilai rata-rata luas tanam pada masing-masing cluster, maka hasil pengelompokan di atas memiliki nilai simpangan baku dalam cluster sebesar 1.611,56 dan nilai simpangan baku antar cluster sebesar 3.330,29. 


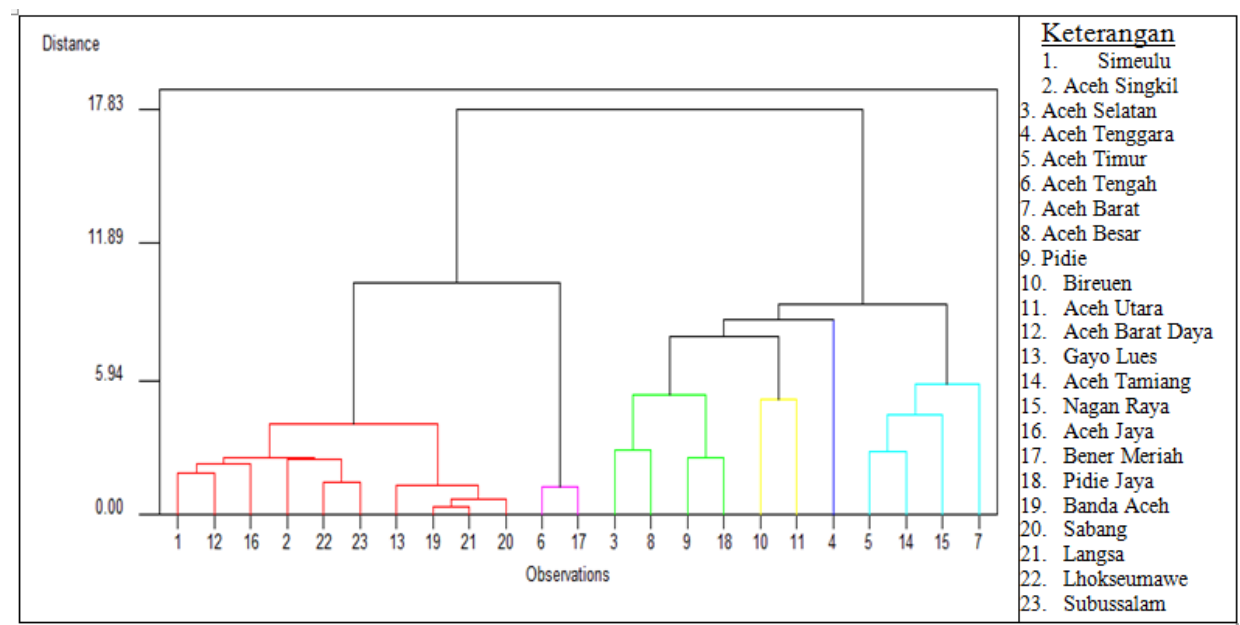

Gambar 3.5. Hasil pengelompokan 6 cluster dengan jarak korelasi Pearson

Pengelompokan kabupaten/kota dengan Metode Ward juga dapat dilakukan dengan jarak Euclidean. Pengelompokan dengan jarak Euclidean dilakukan pada data yang tidak mengandung multikolinearitas. Sehingga masalah multikolinearitas harus terlebih dahulu diatasi sebelum pengelompokan dilakukan. Masalah multikolinearitas dapat diatasi dengan analisis komponen utama.

\section{Pengelompokan dengan Jarak Euclidean}

Hasil analisis korelasi data peubah menyimpulkan bahwa terdapat beberapa korelasi yang tinggi antar peubah. Dari matriks korelasi dapat diturunkan 10 komponen utama (KU), ada lima KU yang memenuhi kriteria pemilihan KU yang dilihat dari nilai akar ciri yang lebih dari 0,7 dan proporsi kumulatif akar ciri pertama mencapai 80\% atau lebih. Proporsi akar ciri selengkapnya disajikan pada Tabel 3.1.

Tabel 3.1 menunjukan bahwa proporsi keragaman $\mathrm{KU}_{1}$ sebesar 0,339 artinya bahwa $\mathrm{KU}_{1}$ dapat menerangkan keragaman data asal sebesar 33,9\% dari keragaman total. Dengan cara yang sama $\mathrm{KU}_{2}, \mathrm{KU}_{3}, \mathrm{KU}_{4}$ dan $\mathrm{KU}_{5}$ masing-masing menerangkan sebesar 17,$3 ; 13,4 ; 10,7$; dan $6,7 \%$ dari keragaman total. Secara kumulatif lima KU tersebut mempunyai proporsi keragaman sebesar 0,84 yang berarti kelima KU mampu menerangkan keragaman data asal sebesar 84\% dari keragaman totalnya.

Table 3.1. Komponen utama (KU) data subsektor tanaman pangan dan perkebunan

\begin{tabular}{|c|c|c|c|c|c|}
\hline Peubah & $\mathrm{KU}_{1}$ & $\mathrm{KU}_{2}$ & $\mathrm{KU}_{3}$ & $\mathrm{KU}_{4}$ & $\mathrm{KU}_{5}$ \\
\hline $\mathrm{X}_{1}$ & 0,45279 & $-0,1533$ & $-0,027$ & 0,07587 & 0,1222 \\
$\mathrm{X}_{2}$ & 0,01701 & $-0,3036$ & $-0,4218$ & 0,4771 & $-0,2949$ \\
$\mathrm{X}_{3}$ & 0,28221 & $-0,1952$ & 0,20477 & $-0,1325$ & 0,09713 \\
$\mathrm{X}_{4}$ & 0,19308 & 0,41904 & $-0,1218$ & $-0,0258$ & $-0,6614$ \\
$\mathrm{X}_{5}$ & 0,40606 & 0,24127 & 0,15235 & 0,1498 & $-0,0653$ \\
$\mathrm{X}_{6}$ & 0,21659 & 0,40904 & 0,19631 & 0,45302 & 0,00094 \\
$\mathrm{X}_{7}$ & 0,18508 & 0,36458 & $-0,3664$ & $-0,1222$ & 0,53859 \\
$\mathrm{X}_{8}$ & 0,22608 & 0,23853 & $-0,4958$ & $-0,1158$ & 0,12604 \\
$\mathrm{X}_{9}$ & 0,21457 & $-0,4002$ & $-0,3535$ & 0,32222 & 0,0642 \\
$\mathrm{X}_{10}$ & 0,39966 & $-0,1651$ & 0,25127 & $-0,1572$ & $-0,1811$ \\
$\mathrm{X}_{11}$ & $-0,119$ & 0,1153 & 0,31739 & 0,59213 & 0,30424 \\
$\mathrm{X}_{12}$ & 0,40086 & $-0,2336$ & 0,18417 & $-0,115$ & 0,10707 \\
\hline Akar ciri & 40,636 & 2,075 & 18,495 & 12,858 & 0,8086 \\
Proporsi & 0,339 & 0,173 & 0,154 & 0,107 & 0,067 \\
Kumulatif & 0,339 & 0,512 & 0,666 & 0,773 & 0,84 \\
\hline
\end{tabular}


Hal ini menyatakan bahwa proses pengelompokan cukup menggunakan lima KU yaitu $\mathrm{KU}_{1}, \mathrm{KU}_{2}, \mathrm{KU}_{3}, \mathrm{KU}_{4}$ dan $\mathrm{KU}_{5}$ karena kelima $\mathrm{KU}$ telah mampu menerangkan keragaman data luas tanam kedua subsektor sebesar $84 \%$. Secara visual nilai-nilai akar ciri dilihat polanya seperti pada gambar di bawah ini:

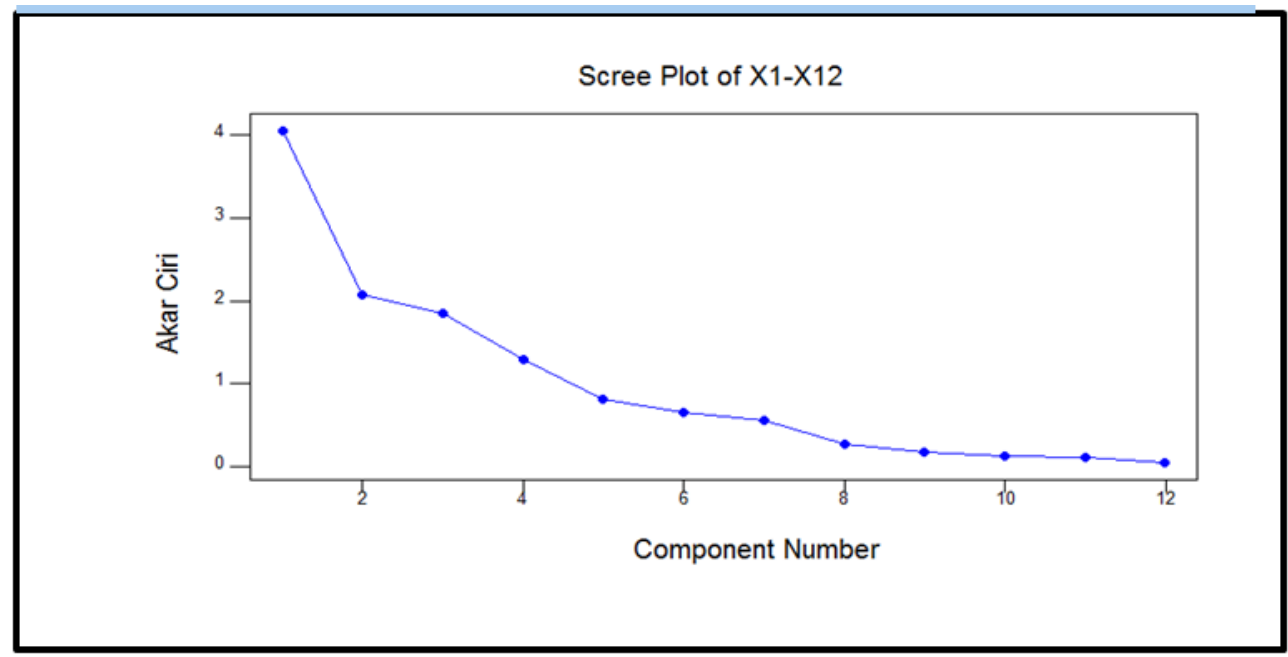

Gambar 3.6. Plot nilai-nilai akar ciri untuk data subsektor tanaman pangan dan perkebunan

Gambar 3.6 titik ke-5 menunjukan bahwa plot curam ke kiri tetapi tidak curam ke kanan. Hal ini berarti ada lima KU yang dapat digunakan untuk pengelompokan. Dari kelima KU tersebut diperoleh skor komponen utama (W) yaitu $\mathrm{W}_{1}, \mathrm{~W}_{2}, \mathrm{~W}_{3}, \mathrm{~W}_{4}$ dan $\mathrm{W}_{5}$.

Selanjutnya setelah skor komponen utama diperoleh, kemudian dilakukan pengelompokan terhadap skor komponen utama menggunakan jarak Euclidean. Pengelompokan kabupaten/kota dikelompokan menjadi tiga cluster, empat cluster, lima cluster dan enam cluster.

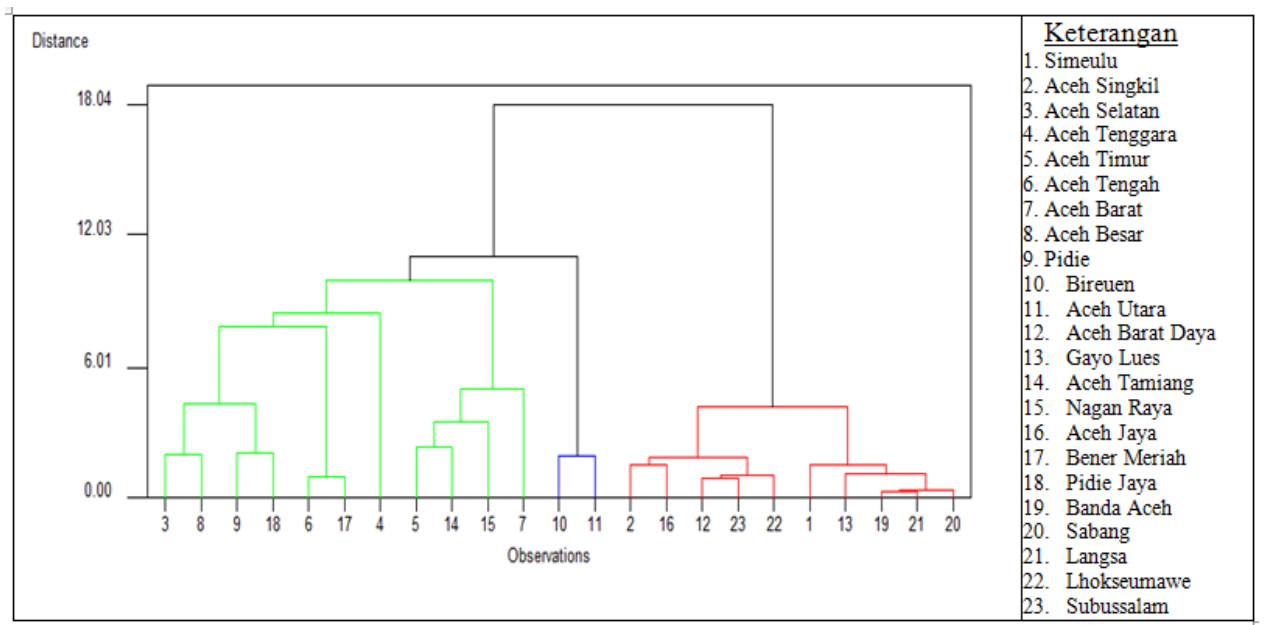

Gambar 3.7. Hasil pengelompokan 3 cluster dengan jarak Euclidean

Hasil pengelompokan kabupaten/kota berdasarakan indikator tanaman pangan dan perkebunan dengan jarak Euclidean untuk tiga cluster dapat dilihat pada Gambar 4.19. Berdasarkan Gambar 3.7 diperoleh anggota-anggota cluster hasil pengelompokan kabupaten/kota dengan jarak Euclidean untuk tiga cluster yaitu:

1) Cluster I : Kabupaten Aceh Selatan, Aceh Besar, Pidie, Pidie Jaya, Aceh Tengah, Bener Meriah, Aceh Tenggara, Aceh Timur, Aceh Tamiang, Nagan Raya dan Aceh Barat.

2) Cluster II : Kabupaten Bireuen dan Aceh Utara.

3) Cluster III : Kabupaten Aceh Singkil, Aceh Jaya, Aceh Barat Daya, Subussalam, Lhokseumawe, Simeulu, Gayo Lues, Banda Aceh, Langsa dan Sabang. 
Berdasarkan nilai rata-rata luas tanam pada masing-masing cluster (Lampiran 14), maka hasil pengelompokan di atas memiliki nilai simpangan baku dalam cluster sebesar 2.659,48 dan nilai simpangan baku antar cluster sebesar 4.260,51.

Hasil pengelompokan kabupaten/kota dengan empat cluster pada Gambar 3.8. Berdasarkan Gambar 3.8 diperoleh anggota-anggota kelompok hasil pengelompokan kabupaten/kota dengan jarak Euclidean untuk empat cluster yaitu:

1) Cluster I : Kabupaten Aceh Selatan, Aceh Besar, Pidie, Pidie Jaya, Aceh Tengah, Bener Meriah dan Aceh Tenggara.

2) Cluster II : Kabupaten Bireuen dan Aceh Utara.

3) Cluster III : Kabupaten Aceh Singkil, Aceh Jaya, dan Aceh Barat Daya, Subussalam, Lhokseumawe, Simeulu, Gayo Lues, Banda Aceh, Langsa dan Sabang.

4) Cluster IV : Kabupaten Aceh Timur, Aceh Tamiang, Nagan Raya dan Aceh Barat.

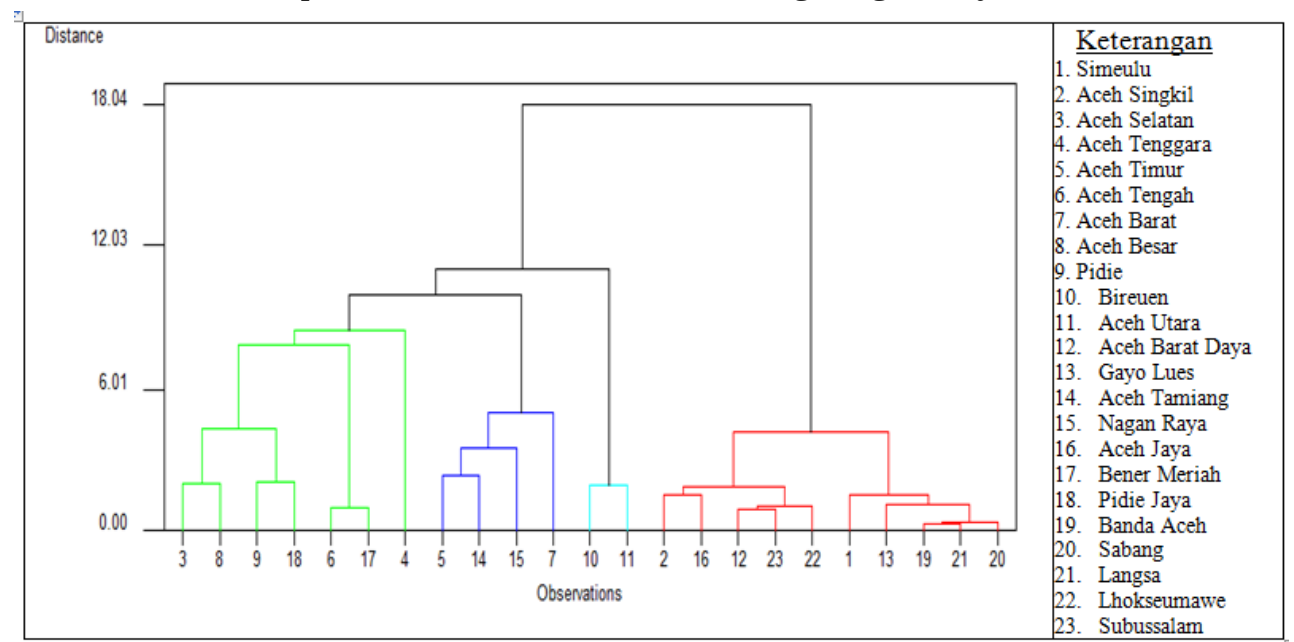

Gambar 3.8. Hasil pengelompokan empat cluster dengan jarak Euclidean

Berdasarkan nilai rata-rata luas tanam pada masing-masing cluster maka hasil pengelompokan empat cluster di atas memiliki nilai simpangan baku dalam cluster sebesar 2.371,76 dan nilai simpangan baku antar cluster sebesar 4.041,04.

Hasil pengelompokan kabupaten/kota dengan lima cluster dapat dilihat gambar berikut:

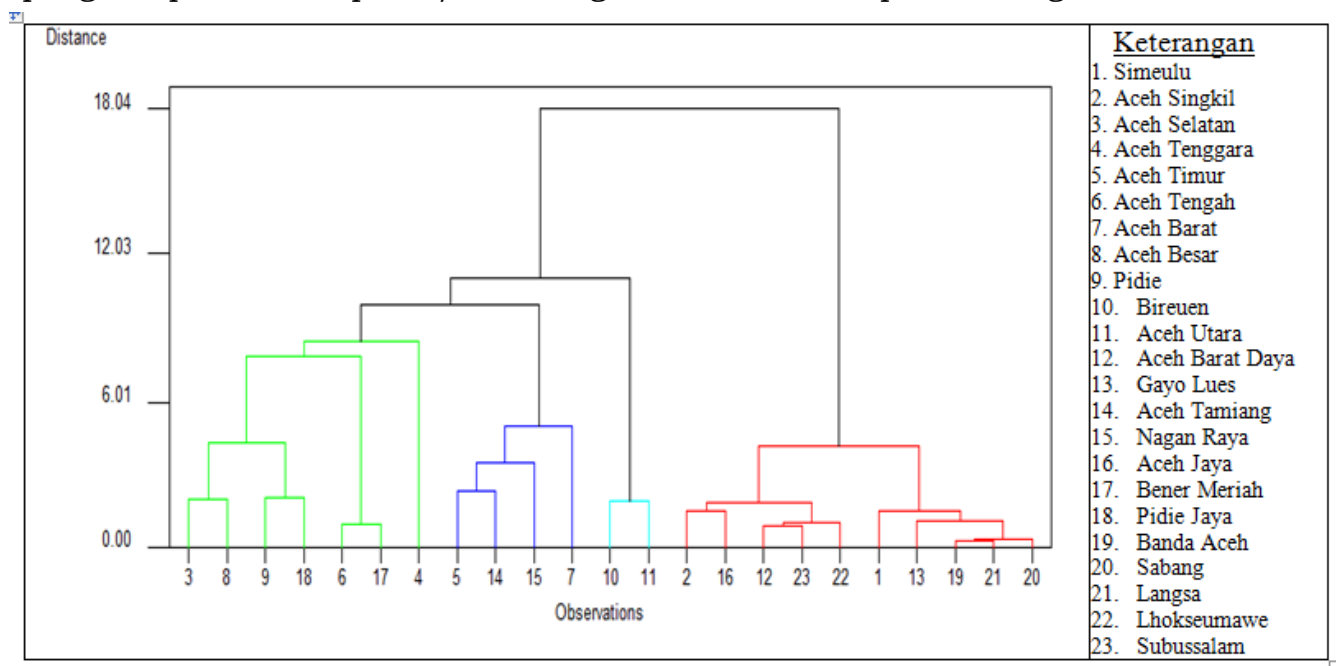

Gambar 3.9. Hasil pengelompokan lima cluster dengan jarak Euclidean

Berdasarkan Gambar 3.9 diperoleh anggota-anggota kelompok hasil pengelompokan kabupaten/kota dengan jarak Euclidean untuk lima cluster yaitu: 
1) Cluster I : Kabupaten Aceh Selatan, Aceh Besar, Pidie, Pidie Jaya, Aceh Tengah dan Bener Meriah.

2) Cluster II : Kabupaten Bireuen dan Aceh Utara.

3) Cluster III : Kabupaten Aceh Singkil, Aceh Jaya, dan Aceh Barat Daya, Subussalam, Lhokseumawe, Simeulu, Gayo Lues, Banda Aceh, Langsa dan Sabang.

4) Cluster IV : Kabupaten Aceh Timur, Aceh Tamiang, Nagan Raya dan Aceh Barat.

5) Cluster V : Kabupaten Aceh Tenggara.

Berdasarkan nilai rata-rata luas tanam pada masing-masing cluster, maka hasil pengelompokan di atas memiliki nilai simpangan baku dalam cluster sebesar 1.816,9 dan nilai simpangan baku antar cluster sebesar 3.589,12.

Hasil pengelompokan kabupaten/kota dengan enam cluster dapat dilihat pada gambar berikut:

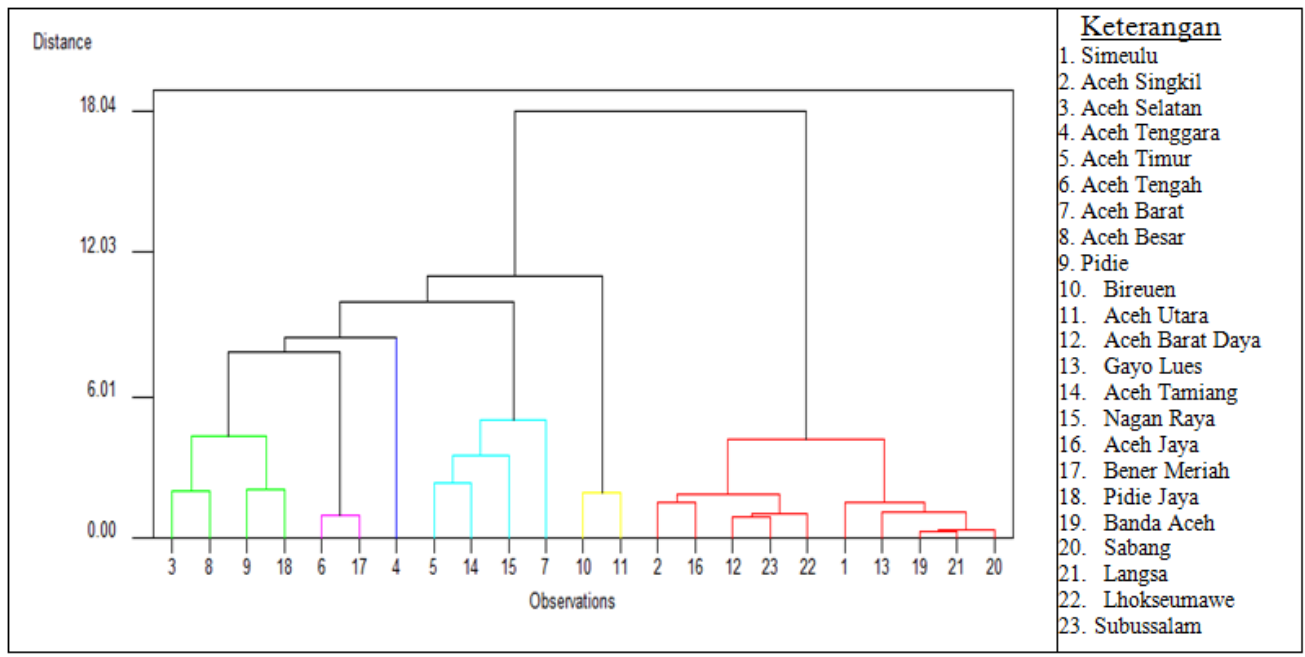

Gambar 3.10. Hasil pengelompokan enam cluster dengan jarak Euclidean

Berdasarkan Gambar 3.10 diperoleh anggota-anggota kelompok hasil pengelompokan kabupaten/kota dengan jarak Euclidean untuk enam cluster yaitu:

1) Cluster I : Kabupaten Aceh Selatan, Aceh Besar, Pidie, dan Pidie Jaya.

2) Cluster II : Kabupaten Bireuen dan Aceh Utara.

3) Cluster III : Kabupaten Aceh Singkil, Aceh Jaya, dan Aceh Barat Daya, Subussalam, Lhokseumawe, Simeulu, Gayo Lues, Banda Aceh, Langsa dan Sabang.

4) Cluster IV : Kabupaten Aceh Timur, Aceh Tamiang, Nagan Raya dan Aceh Barat.

5) Cluster V : Kabupaten Aceh Tenggara.

6) Cluster VI : Kabupaten Aceh Tengah dan Bener Meriah.

Berdasarkan nilai rata-rata luas tanam pada masing-masing cluster), maka hasil pengelompokan di atas memiliki nilai simpangan baku dalam cluster sebesar 1.611,56 dan nilai simpangan baku antar cluster sebesar 3.330,29.

\section{Pemilihan Hasil Pengelompokan Terbaik}

Untuk mengetahui baiknya hasil pengelompokan, dapat digunakan kriteria dua simpangan baku, yaitu simpangan baku dalam cluster (Vw) dan simpangan baku antar cluster (Vb). Hasil pengelompokan terbaik memiliki nilai rasio simpangan baku dalam cluster dan simpangan baku antar cluster yang paling kecil.

Berdasarkan nilai simpangan baku dalam cluster dan simpangan baku antar cluster masingmasing hasil pengelompokan. Maka rasio simpangan baku dalam cluster dan simpangan baku antar cluster dapat dilihat pada Tabel 3.2. 
Tabel 3.2. Rasio simpangan baku dalam dan antar cluster

\begin{tabular}{|c|c|c|c|c|c|c|}
\hline \multirow{2}{*}{$\begin{array}{c}\text { Jumlah } \\
\text { Cluster }\end{array}$} & \multicolumn{3}{|c|}{ Korelasi pearson } & \multicolumn{3}{c|}{ Euclidean } \\
\cline { 2 - 7 } & $\begin{array}{c}\text { Dalam } \\
\text { Cluster }\end{array}$ & $\begin{array}{c}\text { Antar } \\
\text { Cluster }\end{array}$ & Rasio & $\begin{array}{c}\text { Dalam } \\
\text { Cluster }\end{array}$ & $\begin{array}{c}\text { Antar } \\
\text { Cluster }\end{array}$ & Rasio \\
\hline 3 & $1.864,68$ & $2.941,8$ & 0,63386 & $2.659,48$ & $4.260,51$ & 0,62422 \\
\hline 4 & $2.125,83$ & 3.308 & 0,64263 & $2.371,76$ & $4.041,04$ & 0,58692 \\
\hline 5 & $1.755,01$ & $2.983,63$ & 0,58821 & $1.816,9$ & $3.589,12$ & 0,50623 \\
\hline 6 & $1.611,56$ & $3.330,29$ & 0,48391 & $1.611,56$ & $3.330,29$ & 0,48391 \\
\hline
\end{tabular}

Tabel 3.2 menunjukan bahwa nilai rasio simpangan baku dalam cluster dan simpangan baku antar cluster pengelompokan kabupaten/kota menggunakan Metode Ward dengan jarak Euclidean lebih kecil dibandingkan pengelompokan dengan jarak korelasi Pearson untuk setiap jumlah cluster yang terbentuk. Hal ini bermakna pengelompokan kabupaten/kota menggunakan Metode Ward dengan jarak Euclidean lebih baik dibandingkan pengelompokan dengan jarak korelasi Pearson.

Jumlah cluster terbaik untuk pengelompokan kabupaten/kota yang digunakan dalam penelitian ini adalah pengelompokan dengan enam cluster. Hal ini dikarenakan rasio simpangan baku untuk enam cluster merupakan nilai rasio terendah dibandingkan jumlah cluster lainnya.

\section{Komoditas Dominan Setiap Cluster}

Karakteristik potensi komoditas untuk masing-masing cluster pada enam cluster diinterpretasikan berdasarkan nilai rata-rata komoditas tiap cluster. Nilai rata-rata komoditas tiap cluster untuk masing-masing cluster dapat dilihat pada Tabel 3.3 berikut.

Berdasarkan nilai rata-rata tertinggi setiap cluster pada Tabel 3.3 dapat dikatakan bahwa:

1) Cluster 1 merupakan cluster yang tidak memiliki rata-rata peubah tertinggi untuk semua peubah. Hal ini berarti Kabupaten Aceh Selatan, Aceh Besar, Pidie, dan Pidie Jaya tidak memiliki komoditas dominan pada subsektor tanaman pangan dan perkebunan..

2) Cluster 2 merupakan cluster yang memiliki rata-rata tertinggi pada peubah $\mathrm{X}_{1}, \mathrm{X}_{3}, \mathrm{X}_{5}$, $\mathrm{X}_{10}$ dan $\mathrm{X}_{12}$. Hal ini berarti Kabupaten Bireuen dan Aceh Utara memiliki komoditas dominan berupa komoditas padi, kedelai, ubi kayu, kelapa dan pinang.

3) Cluster 3 merupakan cluster tidak memiliki rata-rata peubah tertinggi pada semua peubah. Hal ini berarti rata-rata Kabupaten Aceh Singkil, Aceh Jaya, dan Aceh Barat Daya, Subussalam, Lhokseumawe, Simeulu, Gayo Lues, Banda Aceh, Langsa dan Sabang tidak memiliki komoditas dominan pada subsektor tanaman pangan dan perkebunan.

4) Cluster 4 merupakan cluster yang memiliki rata-rata peubah yang paling tinggi dibandingkan cluster lainnya pada peubah $\mathrm{X}_{4}, \mathrm{X}_{7}$ dan $\mathrm{X}_{8}$. Hal ini berarti Kabupaten Aceh Timur, Aceh Tamiang, Nagan Raya dan Aceh Barat memiliki komoditas dominan berupa komoditas kacang tanah, kelapa sawit dan karet.

5) Cluster 5 merupakan cluster yang memiliki rata-rata peubah yang tinggi pada peubah $\mathrm{X}_{2} \mathrm{X}_{9}$. Hal ini berarti Kabupaten Aceh Tenggara memiliki komoditas dominan berupa komoditas jagung dan kakao.

6) Cluster 6 merupakan cluster yang memiliki rata-rata peubah yang tinggi pada peubah $\mathrm{X}_{6}$ dan $\mathrm{X}_{11}$. Hal ini berarti Kabupaten Aceh Tengah dan Bener Meriah memiliki komoditas dominan berupa komoditas ubi jalar dan kopi. 
Tabe1 3.3. Rata-rata komoditas dalam cluster

\begin{tabular}{|l|r|r|r|r|r|r|}
\hline \multirow{2}{*}{ Komoditas } & \multicolumn{7}{c|}{ Cluster } \\
\cline { 2 - 7 } & \multicolumn{1}{|c|}{1} & \multicolumn{1}{c|}{2} & \multicolumn{1}{c|}{3} & \multicolumn{1}{c|}{4} & \multicolumn{1}{c|}{5} & \multicolumn{1}{c|}{6} \\
\hline Padi $\left(\mathrm{X}_{1}\right)$ & 27521,8 & $\mathbf{5 3 8 5 6}$ & 4116,6 & $26.385,8$ & 2.3130 & $5.124,5$ \\
\hline Jagung $\left(\mathrm{X}_{2}\right)$ & 2096,75 & 1243 & 262,7 & 755 & $\mathbf{2 9 . 9 0 4}$ & 368 \\
\hline Kedelai $\left(\mathrm{X}_{3}\right)$ & $1.313,75$ & $\mathbf{1 3 . 4 4 9 , 5}$ & 44,5 & 2.056 & 0 & 451,5 \\
\hline Kacang Tanah $\left(\mathrm{X}_{4}\right)$ & 188,25 & 159 & 56 & $\mathbf{3 3 7 , 7 5}$ & 47 & 50,5 \\
\hline Ubi Kayu $\left(\mathrm{X}_{5}\right)$ & 199,75 & $\mathbf{2 6 0}$ & 53 & 197,5 & 38 & 110,5 \\
\hline Ubi Jalar $\left(\mathrm{X}_{6}\right)$ & 73 & 65,5 & 15,2 & 77,25 & 6 & $\mathbf{9 7 , 5}$ \\
\hline Kelapa Sawit $\left(\mathrm{X}_{7}\right)$ & $3.083,75$ & 15.067 & $11.861,7$ & $\mathbf{5 5 . 8 5 7 , 5}$ & 7.454 & 650 \\
\hline Karet $\left(\mathrm{X}_{8}\right)$ & 578,75 & $7.908,5$ & $2.655,4$ & $\mathbf{2 3 . 9 1 3 , 6}$ & 12.141 & 0 \\
\hline Kakao $\left(\mathrm{X}_{9}\right)$ & $7.069,5$ & $8.166,5$ & $1.432,2$ & $5.198,5$ & $\mathbf{1 9 . 9 9 4}$ & $1.687,5$ \\
\hline Kelapa $\left(\mathrm{X}_{10}\right)$ & 8.227 & $\mathbf{1 5 . 5 1 8}$ & $2.670,3$ & $2.891,5$ & 760 & 51,5 \\
\hline Kopi $\left(\mathrm{X}_{11}\right)$ & 3.180 & 491,5 & 685,3 & 307,5 & 72 & $\mathbf{5 0 . 9 5 3}$ \\
\hline Pinang $\left(\mathrm{X}_{12}\right)$ & $1.765,75$ & $\mathbf{1 0 . 0 2 3}$ & 477,2 & $1.190,5$ & 439 & 170 \\
\hline
\end{tabular}

\section{KESIMPULAN DAN SARAN}

Berdasarkan hasil penelitian dapat diambil kesimpulan sebagai berikut:

1) Pengelompokan kabupaten/kota menggunakan Metode Ward dengan jarak Euclidean lebih baik dibandingkan dengan jarak korelasi Pearson karena memiliki rasio simpangan baku lebih rendah pada setiap hasil pengelompokan.

2) Hasil pengelompokan kabupaten/kota dengan jarak Euclidean yang terbaik adalah enam cluster dengan rasio simpangan baku dalam cluster sebesar 1.611,56 dan simpangan antar cluster sebesar 3.330,29. Anggota dan karakteristik setiap cluster adalah sebagai berikut:

- Cluster I : Kabupaten Aceh Selatan, Aceh Besar, Pidie, dan Pidie Jaya tidak memiliki komoditas dominan pada subsektor tanaman pangan dan perkebunan.

- Cluster II : Kabupaten Bireuen dan Aceh Utara dengan komoditas dominan berupa komoditas padi, ubi kayu, kelapa dan pinang.

- Cluster III : Kabupaten Aceh Singkil, Aceh Jaya, dan Aceh Barat Daya, Subussalam, Lhokseumawe, Simeulu, Gayo Lues, Banda Aceh, Langsa dan Sabang tidak memiliki komoditas dominan pada subsektor tanaman pangan dan perkebunan.

- Cluster IV : Kabupaten Aceh Timur, Aceh Tamiang, Nagan Raya dan Aceh Barat dengan komoditas dominan berupa komoditas kacang tanah, kelapa sawit dan karet.

- Cluster V : Kabupaten Aceh Tenggara dengan komoditas dominan berupa komoditas jagung dan kakao.

- Cluster VI : Kabupaten Aceh Tengah dan Bener Meriah dengan komoditas dominan berupa komoditas ubi jalar dan kopi.

Berdasarkan hasil penelitian, maka saran-saran yang dapat disampaikan kepada peneliti selanjutnya adalah:

1) Jika terdapat multikolinearitas, maka sebelum melakukan pengelompokan sebaiknya terlebih dahulu mengatasi masalah multikolinearitas.

2) Selain analisis komponen utama, dapat digunakan teknik analisa lainnya untuk mengatasi multikolinearitas. 


\section{DAFTAR PUSTAKA}

-----. 2013. Aceh dalam Angka 2013, BPS Provinsi Aceh, Aceh.

-----. 2013. Analisis Hasil Lengkap Sensus Pertanian 2013, BPS Provinsi Aceh, Aceh.

-----. 2013. Laporan Hasil Sensus Pertanian 2013 (Pencacahan Lengkap), BPS Provinsi Aceh, Aceh.

----. 2014. Aceh dalam Angka 2014, BPS Provinsi Aceh, Aceh.

Barakbah, A. R dan Arai, K. 2004. Determining Constraints of Moving Variance to Find Optimum and Make Automatic Clustering. ITS, Surabaya.

Cornish, R (Mathematics Learning Support Centre). 2007. Statistics : Cluster Analysis. http://www.statstutor.ac.uk/resources/uploaded/clusteranalysis.pdf. Tanggal akses 25 Mei 2015.

Field, $\quad$ A. 2000. Postgraduate Statistic, Cluster Analysis. http://www.statisticshell.com/docs/cluster.pdf. Tanggal akses 25 Mei 2015.

Johnson, A. R. dan Winchern, W. D. 2007. Applied Multivariate Analysis 6th edition. Person Internasional Edition. Inc.

Mattjik, A. dan Sumertajaya. 2011. Sidik Peubah Ganda. IPB, Bogor.

Oktavia, S, Muhlasah, dan Neva. 2013. Pengelompokan Kinerja Dosen Jurusan Matematika FMIPA Berdasarkan penilaian mahasiswa menggunakan metode Ward. Buletin. Universitas Tanjungpura, Pontianak

Rencher, C. A. 2002. Methods of Multivariate Analysis, 2nd edition. John Wiley and Sons, Canada.

Safitri, W. D. 2012. Pengelompokan Kabupaten/Kota Berdasarkan Tingkat Perubahan Kesejahteraan Rakyat. Skripsi. Universitas Syiah Kuala, Banda Aceh.

Vijverbeg, A. 2007. Clustering Microarray Data. Pomona, Spring. 